Open Academic Journal of Advanced Science and Technology

ISSN 2577-7807

Vol. 2, No. 1, pp. 5-8

2018

DOI: $10.33094 / 5.2017 .2018 .21 .5 .8$

(C) 2018 by the authors; licensee Online Academic Press, USA

\title{
Impact of Various Levels of Nitrogen and Phosphorus on Growth and Yield of Spinach (Spinacea oleracea L.) under Conditions of Mansehra (Pakistan)
}

\author{
Qamar-uz-Zaman \\ F.S.Hamid ${ }^{2}$ \\ Shams-ul- Islam ${ }^{3}$ \\ Fayaz Ahmad ${ }^{4}$ \\ Naveed Ahmad ${ }^{5}$
}

Licensed:

This work is licensed under a Creative Commons Attribution 4.0 License.

Keywords:

$N P$

plant growth

Spinach (Spinacea oleracea L.)

Pakistan.

\begin{abstract}
This experiment was studied at PARC National Tea and High Value Crops Research Institute Shinkiari, Mansehra, (Pakistan) during the, 2016-17. The experiment was conducted in Randomized Complete Block design with split plot arrangement including treatments namely $T_{1}(O-O), T_{2}(25-50), T_{s}(50-$ 60), $T_{4}(75-70), T_{5}(100-80), T_{6}(125-90)$ and $T_{7}(150-100) \mathrm{NP} \mathrm{kg} / \mathrm{ha}$. Data revealed that maximum day to first cut (45) was recorded in $T_{1}$ (control plot) as compared to 41 days in $T_{7}$ receiving (150-100) NP $\mathrm{kg} / \mathrm{ha}$. Maximum, plant height of $(27.98 \mathrm{~cm})$, leaf area $\left(231.75 \mathrm{~cm}^{2}\right)$, leaf length $(27.25 \mathrm{~cm})$ was recorded in $T_{7}(150-100) \mathrm{NP} \mathrm{kg} / \mathrm{ha}$ followed by plant height of $(26.10 \mathrm{~cm})$, leaf area $\left(181.75 \mathrm{~cm}^{2}\right)$, leaf length $(25.00 \mathrm{~cm})$ was recorded in $T_{6}$ plot provided $\left(125-90 \mathrm{NP} \mathrm{kg} / \mathrm{ha}\right.$ ) as compared to $15.98 \mathrm{~cm}$ plant height, leaf area $\left(87.5 \mathrm{~cm}^{2}\right)$ and leaf length $(16 \mathrm{~cm})$ in $T_{i}($ without $N P)$. Maximum no. of leaves was recorded in Treatment $T_{6}(21)$ followed by $T_{5}$ and $T_{7}$ where 19 number of leaves/plant recorded. However, lowest no. of leaves (8) obtained in case of $T_{t}$ (without NP). Maximum fresh yield of 23.15 tons/ha was recorded in $T_{7}$, followed by 22.32 tons/ha in $T_{6}$ and 16.80 tons/ha in $T_{5}$ while $T_{1}$ (Without NP fertilizer) produced the lowest spinach fresh leaves yield of 4.844 tons / ha. Nitrogen and phosphorus@125-90 and 150-100 NP kg/ha proved to be optimum dose for getting maximum production from spinach.
\end{abstract}

\section{Introduction}

Spinach (Spinacia oleracea L.).) locally known as Palak, is highly nutritious green leafy vegetable crop of the family Chenopodiaceae Spinach is the most important green leafy winter vegetable grown in Pakistan on a large scale. It is one of the most common herbage vegetable grown for its greens leaves. It is believed that Spinach originated from Central and South West Asia. It is a popular annual winter vegetable crop that can tolerate extreme cold stress. In Pakistan, during 2014-15, the total cropped area of Spinach was 8610 hectares with a production of 104288 tones. During the same years, in Khyber Pakhtunkhwa province, spinach was grown on an area of 1627 hectares with a total production of about 17821 tones [1]. Spinach is normally grown for its delicious and tender green leaves. The leaves of spinach normally attain a height of about $2-30 \mathrm{~cm}$ having a width of about $1-15 \mathrm{~cm}$. Spinach contains various vitamins, including vitamin $\mathrm{C}$, E, and $\mathrm{K}$ and is also a good source of beta carotene. Spinach is an excellent source of iron and various other minerals, including potassium, sulphur, sodium, folic acid and oxalic acid [2]. According to USDA reports, Spinach contains iron absorption-inhibiting substances, including high levels of oxalate, which can bind to the iron to form ferrous oxalate and render much of the iron in spinach unusable by the body. In addition to preventing absorption and use, high levels of oxalates remove iron from the body [3] Spinach generally grows best in cool and moist climate. The low temperature coupled with more humidity encourages the development of succulent and tender leaves. The first cutting is generally performed when the plant produces five to six true leaves. Nutrition of spinach depends mainly up on the three most important elements; i.e., N, P and K mineral fertilizers; because of the relatively higher requirements from these three elements, comparing with the other nutrition elements. Among the nutrients required by plants in a large amount, nitrogen is the most essential and at the same time, one of the most important growth factors in controlling yield and quality of most vegetable crops. The low production of spinach in Pakistan might be due to the influence of several factors, including the less attention of the farmers on land preparation, sowing time, improper application of cultural practices including weeding, irrigation and non judicious use of chemical 
fertilizers especially $\mathrm{N}$ in spinach cultivation. Nitrogen is an essential macronutrient needed by all plants to thrive. It is an important component of many structural, genetic and metabolic compounds in plant cells. Increasing the levels of nitrogen during the vegetative stage can strengthen and support plant roots, enabling plants to take in more water and nutrients; and allows a plant to grow more rapidly and produce large amounts of succulent, green foliage, which in turn can generate bigger yields, tastier vegetables, and a crop that is more resistant to pests, diseases, and other adverse conditions [4]. Similarly, Phosphorus (P) is an essential nutrient both as a part of several key plant structure compounds and as a catalysis in the conversion of numerous key biochemical reactions in plants. $\mathrm{P}$ stimulated root development, increased stem strength, improved flower formation and seed production, more uniform and earlier crop maturity, improvements in crop quality, and increased resistance to plant diseases [5]. Leafy vegetables, particularly, the spinach is highly responsive to fertilization [6] and oxalates which are the main indexes of the quality due to a very efficient uptake system and inefficient reductive systems [7]. Spinach requires a high level of fertility, especially nitrogen. Boroujerdnia and Ansari [8] achieved maximum yield with the application of nitrogen@120 kg ha ${ }^{-1}$. El-Assiouty and Abo-Sedera [9] reported that application of $40 \mathrm{~kg} \mathrm{~N}+15.0 \mathrm{~kg} \mathrm{P} \mathrm{P}_{2} \mathrm{O}_{5}$ increased plant fresh yield by $27.2 \%$ and $42.3 \%$ and $16.3 \%$ and $10.4 \%$ in seed yield over the control in the first and second seasons, respectively. Odueso [10] suggested that N-P-K 20-10-10 was found to be better for growth and yield of spinach. El-Fadaly and Mishriky [11] in his study found that $\mathrm{N}$ increased the spinach yield and enhanced the accumulation of $\mathrm{N}$ and $\mathrm{P}$ in leaves. Darani, et al. [12] reported that the $\mathrm{N}$ levels of 75 to $150 \mathrm{~kg} \mathrm{ha}^{-1}$ are optimum levels for the satisfactory yield of spinach. Luyen and Preston [13] concluded that spinach is a vegetable with a high potential to convert efficiently the nitrogen in urea into edible biomass with high nitrogen content. The authors in Wahocho, et al. [14] reported that low production of spinach in Pakistan might be due to the influence of several factors, including the less attention of the farmers on land preparation, sowing time, improper application of cultural practices including weeding, irrigation and non judicious use of chemical fertilizers especially $\mathrm{N}$ in spinach cultivation Application of nitrogen and phosphorus fertilizers has essential role in the development of crop yield and quality of the produce. Farmers have increased application of nitrogen fertilizers to their land year by year without considering the response of different species to rate of nutrients and their forms. Adequate supply of fertilizers can promote plant growth and increase crop production, but excessive and inappropriate use of chemical fertilizers causes accumulation of compounds in the edible products which have a detrimental impact on human health, cause an environmental pollution and economical losses [15]. The present study was carried out to investigate the influence of different nitrogen and phosphorus levels on the growth and yield of spinach.

\section{Material and Methods}

This study was conducted at, Shinkiari, Mansehra, (Pakistan) during 2016-17 to determine the effect of different levels of nitrogen and phosphorus on yield and other parameters of spinach. Shinkiari is located $18 \mathrm{~km}$ north of Mansehra city on the Karakoram Highway, it is located at $34^{\circ} 28^{\prime} \mathrm{ON}, 73^{\circ} 16^{\prime} 60 \mathrm{E}$ at an altitude of 1019 meters (3346 feet). Soil samples were taken from experimental sites at 0-15 cm, 16-30 cm depth and analyzed for physico-chemical properties before the start of the trial. The type soil at the test site was sandy-loam and the other properties are listed in Table 1. Variety local was used in the experiment. The experiment was conducted as a Randomized Complete Block design with split plot arrangement having seven treatments namely $\mathrm{T}_{1}(\mathrm{O}-\mathrm{O})$, $\mathrm{T}_{2}$ (25-50), $\mathrm{T}_{3}(50-60), \mathrm{T}_{4}(75-70), \mathrm{T}_{5}(100-80), \mathrm{T}_{6}(125-90)$ and $\mathrm{T}_{7}(150-100) \mathrm{NP} \mathrm{kg} / \mathrm{ha}$ and three replications. Nitrogen and phosphorus were applied in the form of urea and single super phosphate. All $\mathrm{P}$ and half nitrogen were applied at the time of land preparation by mixing in the soil, while the remaining $\mathrm{N}$ was applied in two equal doses and were applied with a fortnight interval. Data were recorded from ten randomly selected plants on days to first fruits cut, plant height $(\mathrm{cm})$, No. of leaves plant ${ }^{-1}$, leaf length $(\mathrm{cm})$, leaf area $\left(\mathrm{cm}^{2}\right)$ and fresh leaves yield at various cuts was recorded by harvesting whole plot of $3 \times 4.5 \mathrm{~m}^{2}$ and converted in tons ha $-^{1}$. The data on the above characters were collected and statistical analyses were performed by using statistical computer software package [16].

Table-1. Analysis of soil before start of experiment.

\begin{tabular}{l|l|l|l}
\hline Parameter & Unit & O-15 cm depth & $\mathbf{1 6 - 3 0 c m ~}$ \\
\hline $\mathrm{pH}$ & & 5.79 & 6.74 \\
\hline Electrical conductivity & $u s / \mathrm{cm}$ & 43.4 & 105.3 \\
\hline Organic matter & $\%$ & 1.51 & 1.21 \\
\hline Phosphorus & $m g \mathrm{~kg}^{-I}$ & 61.2 & 36.2 \\
\hline Potassium & $m g \mathrm{~kg}^{-I}$ & 300 & 288 \\
\hline \multicolumn{2}{l}{ Textural class } & Sandy loam & $\mathbf{1 6 - 3 0 c m}$ \\
\hline
\end{tabular}




\section{Results and Discussion}

The data regarding the growth parameters is presented in Table 2. The data indicated that the application of various levels of NP fertilizer has significant effect on the growth parameters expressed as plant height, Number of leaves / plant, leaf size, Leaf area $\mathrm{cm}^{2}$ and total yield (ton/ha.)

\subsection{Days to $1^{\text {st }}$ Cut}

The spinach crop was ready for first cutting in minimum time period ( 41 days) when fertilized with N-P level of 150-100, 125-90 and 100-80 kg ha-1, respectively. Table 2 indicates that the spinach crop given N-P levels @ o0, 25-50 and 50-60 kg ha-1 extended period to reach first cutting stage i.e. 45 days, respectively. The LSD test suggested that the differences in the number of days taken to first cut between N-P levels of 150-100, 125-90 and $100-80 \mathrm{~kg} \mathrm{ha}^{-1}$ were non-significant $(\mathrm{P}>0.05)$.

\subsection{Plant height (cm)}

There was a significant (PO.05) effect of different levels of N-P on spinach plant height (Table-2). Data suggested that $150-100 \mathrm{~kg} \mathrm{ha}^{-1} \mathrm{~N}-\mathrm{P}$ resulted maximum plant height of $27.98 \mathrm{~cm}$ in $\mathrm{T}_{7}$ followed by plant height of $26.10 \mathrm{~cm}$ in $\mathrm{T}_{6}$ provided (125-90 NP kg/ha) and $25.80 \mathrm{~cm}$ in $\mathrm{T}_{5}$ provided (100-80 NP kg/ha) respectively. Minimum plant height of $(15.98 \mathrm{~cm})$ was recorded in $\mathrm{T}_{1}$ (control plot without NP).)

\subsection{No. of Leaves/Plant}

The analysis of variance showed that the differences in the number of leaves plant ${ }^{-1}$ of spinach under different N-P fertilizer levels were statistically significant (Po.05). Data revealed that maximum no. of leaves (21) was achieved in $\mathrm{T}_{6}$ receiving (125-90 NP kg/ha) followed by 19 in $\mathrm{T}_{7}$ and $\mathrm{T}_{5}$ each respectively provided NP@150100 and 100-80 NP kg/ha. The application of lower N-P levels of 25-50, 50-60 NP kg ha-1 resulted in 9 and 12 number of leaves plant-1 , respectively. However, the minimum number of leaves (8) plant ${ }^{-1}$ was recorded from the plot receiving no N-P fertilizers (control). Similar results were reported by Popat and Mahorkar [2] and Liphadzi, et al. [17]. They also reported that the number of leaves and leaf length increased significantly when $\mathrm{N}$ was applied to spinach in optimum quantity.

\subsection{Leaf Length $(\mathrm{cm})$}

The analysis of variance demonstrated that the differences in the leaf length of spinach under different N-P levels were statistically significant (P0.05). The spinach crop fertilized with highest N-P level of 150-100 $\mathrm{kg} \mathrm{ha}^{-1}$ resulted in maximum leaf length of $27.25 \mathrm{~cm}$, and with decrease in N-P fertilizer levels i.e. 125-90, 100-80 and 75$70 \mathrm{~kg} \mathrm{ha}{ }^{-1}$, the leaf length of spinach decreased to $25 \mathrm{~cm}, 23.5$ and $23 \mathrm{~cm}$, respectively. The crop provided N-P fertilizers at the lower rates of 50-60 and $25-50 \mathrm{~kg} \mathrm{ha}^{-1}$ showed decreased leaf length of 22.5 and $17.5 \mathrm{~cm}$, respectively; while the minimum leaf length of $16 \mathrm{~cm}$ was recorded in control plot receiving no N-P fertilizers. Data in Table 2 indicated that there was a significant increase in the leaf length with each increment in the N-P application. . These results are also in agreements with the findings of Liphadzi, et al. [17] and Popat and Mahorkar [2].

\subsection{Leaf Area $\left(\mathrm{cm}^{2}\right)$}

Leaf area is the most import characteristic in spinach which play important role in production. Data in Table2 suggest that maximum leaf area of $231.75 \mathrm{~cm}^{2}$ was recorded in $\mathrm{T}_{7}$ provided with $150-100 \mathrm{NP} \mathrm{kg} \mathrm{ha-1}$ followed by $181.75 \mathrm{~cm}^{2}$ and $168 \mathrm{~cm}$ leaf area in $\mathrm{T}_{6}$ receiving $125-90 \mathrm{NP} \mathrm{kg} \mathrm{ha-1}$ and in $T_{5}\left(100-80 \mathrm{NP} \mathrm{kg} \mathrm{ha}{ }^{-1}\right)$. Treatment $\left(T_{1}\right.$ without NP fertilizer) produced the lowest leaf area of $\left(87.5 \mathrm{~cm}^{2}\right)$.

\subsection{Fresh Leaves Yield Tons /ha.}

Data regarding fresh leaves yield of spinach in four cuts is presented in Table-2. Increasing levels of both fertilizers showed superiority over control and yield increased with increasing levels of NP fertilizers. The analysis of variance indicates that the spinach yield ha $^{-1}$ was significantly (P0.05) affected by NP fertilizers at different levels. It is evident from the results that the highest spinach yield ha-1 $(23.15$ tons) was obtained from the plots supplied with highest N-P level of $150-100 \mathrm{~kg} \mathrm{ha}^{-1}$, closely followed by 22.33 tons yield ha-1 under N-P application of $125-90 \mathrm{~kg} \mathrm{ha}^{-1}$. The application of N-P fertilizers at the rates of $100-80$ and $75-70 \mathrm{~kg} \mathrm{ha}^{-1}$ resulted in a decreased yield of 16.800 tons and 13.06 tons ha-1, respectively. The spinach yield was further reduced to 11.40 tons and 9.46 tons ha-1 when the crop was supplied with $50-60$ and $25-50 \mathrm{~kg} \mathrm{ha}^{-1} \mathrm{~N}-\mathrm{P}$ levels, respectively. However, the lowest yield 4.84 tons $\mathrm{ha}^{-1}$ was obtained from the control plots where no N-P fertilizers were applied. This higher yield under higher N-P levels was coupled with increased plant height, more leaves plant ${ }^{-1}$, no. of leaves and higher leaf length. Hence, for achieving economically higher spinach yield $\mathrm{ha}^{-1}$ the optimum N-P level would be $125-90 \mathrm{~kg}^{-} \mathrm{ha}^{-}$ 
${ }^{1}$ and $150-100 \mathrm{~kg} \mathrm{ha}^{-1}$. These results are in line with those of Canali, et al. [18] and Popat and Mahorkar [2] who suggested that spinach requires a high level of fertility in soils and $\mathrm{N}$ application up to $150 \mathrm{~kg} \mathrm{ha}^{-1}$ is best dose for spinach.

\begin{tabular}{|c|c|c|c|c|c|c|}
\hline $\begin{array}{l}\text { Treatment } \\
\text { NP kg/ha }\end{array}$ & $\begin{array}{l}\text { Days to } 1^{\text {st }} \\
\text { cut }\end{array}$ & $\begin{array}{l}\text { Plant } \\
\text { height }(\mathbf{c m})\end{array}$ & $\begin{array}{l}\text { No. of } \\
\text { leaves/plant }\end{array}$ & $\begin{array}{l}\text { Leaf length } \\
(\mathrm{cm})\end{array}$ & $\begin{array}{l}\text { Leaf } \\
\operatorname{area}\left(\mathrm{cm}^{2}\right)\end{array}$ & $\begin{array}{l}\text { Fresh leaves } \\
\text { yield tons/ha. }\end{array}$ \\
\hline $\mathrm{T}_{1}(\mathrm{O}-\mathrm{O})$ & $45 \mathrm{a}$ & $15.98 \quad \mathrm{~d}$ & $8 \mathrm{~d}$ & $16 \mathrm{c}$ & $87.5 \mathrm{e}$ & $5.84 \mathrm{~d}$ \\
\hline $\mathrm{T}_{2}(25-50)$ & $45 \mathrm{a}$ & $20.16 \mathrm{~cd}$ & $9 \mathrm{~d}$ & $17.5 \mathrm{c}$ & $119 \mathrm{de}$ & $9.46 \mathrm{c}$ \\
\hline $\mathrm{T}_{3}(5 \mathrm{O}-6 \mathrm{O})$ & $45 \mathrm{a}$ & $19.33 \mathrm{~cd}$ & $12 \mathrm{~cd}$ & $22.5 \mathrm{~b}$ & $122 \mathrm{cde}$ & $11.40 \mathrm{c}$ \\
\hline $\mathrm{T}_{4}(75-70)$ & $41 \mathrm{~b}$ & 23.33 bc & $15 \mathrm{bc}$ & $23 \mathrm{~b}$ & $157.5 \mathrm{bcd}$ & $13.05 \mathrm{bc}$ \\
\hline $\mathrm{T}_{5}(100-80)$ & $41 \mathrm{~b}$ & $25.80 \mathrm{ab}$ & $19 \mathrm{ab}$ & $23.5 \mathrm{ab}$ & $168 \mathrm{bc}$ & $16.79 \mathrm{~b}$ \\
\hline $\mathrm{T}_{6}(125-90)$ & $41 \mathrm{~b}$ & $26.10 \mathrm{ab}$ & $21 \mathrm{a}$ & $25 \mathrm{ab}$ & $181.75 \mathrm{~b}$ & $22.32 \mathrm{a}$ \\
\hline $\mathrm{T}_{7}(150-100)$ & $41 \mathrm{~b}$ & $27.98 \mathrm{a}$ & $19 \mathrm{ab}$ & $27.25 \mathrm{a}$ & $231.75 \mathrm{a}$ & $23.15 \mathrm{a}$ \\
\hline LSD $0.05 \%$ & 0.9 & 4.43 & 5.81 & 3.83 & 46.21 & 4.41 \\
\hline $\mathrm{CV} \%$ & 0.88 & 8 & 16.22 & 7.09 & 12.28 & 9.29 \\
\hline
\end{tabular}

Source: PARC National Tea and High Value Crops Research Institute Shinkiari(Mansehra)Pakistan.

\section{Conclusions}

Fertilizer has significant effect on the growth and yield of crops as application of balanced fertilizer is most important to obtain maximum growth and yield of crops. In our study, it was observed that fertilizer level applied (a) 150-100 NP for obtaining better yield of spinach may be recommended as the yield of spinach was highest in $\mathrm{T}_{7}$ where dose of N-P fertilizer levels of 150-100 was applied.

\section{References}

[1] GOP, "Fruits, vegetables and condiments statistics of Pakistan (2014-15). Ministry of National Food Security \& Research, Islamabad " pp. 11-12, 2014.

[2] J. R. Popat and V. K. Mahorkar, "Effect of NPK through foliar application on growth and yield of Indian spinach," Annals of Plant Physiology, vol. 23, pp. 201-203, 2009.

[3] USDA, "USDA national nutrient database for standard reference, release 18. Nutrient Data Laboratory. U.S. Department of Agriculture, Agricultural Research Service." Retrieved from http://www.nal.usda.gov/fnic/foodcomp, 2005.

[4] D. Eckert, "Efficient fertilizer use of nitrogen," 2nd ed New York: John Willy and Sons, 2010, pp. 1-19.
$[5] \quad$ B. Griffith, "Efficient fertilizer use - phosphorus," 2nd ed Amsterdam: McMillan Co, 2010, pp. 1-7.

[6] D. Cantliffe, "Nitrate accumulation in vegetable crops as affected by photoperiod and light duration (beets, radish, spinach, beans)," Journal of the American Society for Horticultural Science, vol. 97, pp. 414- 418, 1992.

[7] G. Jaworska, "Content of nitrates, nitrites, and oxalates in New Zealand spinach," Food Chemistry, vol. 89, pp. 235242, 2005

[8] M. Boroujerdnia and N. A. Ansari, "Effect of different levels of nitrogen fertilizer and cultivars on growth, yield and yield components of romaine lettuce (Lactuca sativa L.)," Middle Eastern and Russian Journal of Plant Science and Biotechnology, vol. 1, pp. 47-53, 2007.

[9] F. M. M. El-Assiouty and S. A. Abo-Sedera, "Effect of bio and chemical fertilizers on seed production and quality of spinach (Spinacia oleracea L.)," International Journal of Agriculture \& Biology, vol. 7, pp. 947-952, 2005.

[10] O. O. Odueso, "The effects of fertilizers on the growth and yield of Indian spinach (Basella alba)," Journal of Science and Technology in Greenhouse Culture, vol. 1, pp. 4- 5, 2011.

[11] K. A. El-Fadaly and J. F. Mishriky, "Effect of nitrogen sources and levels on growth, yield and mineral composition of spinach," Bulletin of Faculty of Agriculture, University of Cairo, vol. 41, pp. 973-988, 2000.

[12] F. H. Darani, H. Zeinali, A. H. S. Rad, A. Khourgami, and H. Nasrollahi, "Effect of planting date and nitrogen fertilizer on two varieties (inner and outer) of spinach," Annals of Biological Research, vol. 4, pp. 56-59, 2013.

[13] L. T. Luyen and T. R. Preston, "Effect of level of urea fertilizer on biomass production of water spinach (Ipomoea aquatica) grown in soil and in water," Livestock Research for Rural Development, vol. 16, pp. 67- 73, 2004.

[14] N. A. Wahocho, N. Memon, M. N. Kandhro, T. F. Miano, K. H. Talpur, and S. A. Wahocho, "Response of nitrogen on the growth and productivity of spinach (Spinacia oleracea L.)," Sindh University Research Journal, vol. 48, pp. 305-308, 2016.

[15] Z. H. Wang, Z. Q. Zong, S. X. Li, and B. M. Chen, "Nitrate accumulation in vegetables and its residual in vegetable fields," Environmental Science, vol. 23, pp. 79-83, 2002.

[16] B. Statistix, "Statistics 8 user guide, version Analytical software, Tallahassee 32317 USA. Copyright @ 2006 by Analytical software," 2006.

[17] K. B. Liphadzi, M. Maboko, and J. Viljoen, "Spinach growth and yield response to reduced fertilizer application and irrigation," ASA-CSSA-SSSA. International Meetings, India. November, 2006, pp. 12-16, 2006.

[18] S. Canali, F. Montemurro, F. Tittarelli, and O. Masetti, "Effect of nitrogen fertilisation reduction on yield, quality and N utilisation of processing spinach," Journal of Food, Agriculture Eீ Environment, vol. 6, pp. 242-247, 2008. 